\title{
Psycho-educational Groups for People With Amyotrophic Lateral Sclerosis and Their Caregiver: a Qualitative Study
}

\section{Vittoria Anita Bilenchi}

Catholic University of the Sacred Heart

Paolo Innocente Banfi

IRCCS Fondazione Don Carlo Gnocchi

Francesco Pagnini

Catholic University of the Sacred Heart

Eleonora Volpato ( $\nabla$ eleonora.volpato@unicatt.it)

Catholic University of the Sacred Heart

\section{Research Article}

Keywords: Psychoeducational groups, Amyotrophic Lateral Sclerosis (ALS), Caregivers, Qualitative methodology, Grounded Theory (GT), Interpretative Phenomenological Analysis (IPA)

Posted Date: March 18th, 2021

DOI: https://doi.org/10.21203/rs.3.rs-318649/v1

License: (c) (i) This work is licensed under a Creative Commons Attribution 4.0 International License. Read Full License 


\section{Abstract}

Background: Amyotrophic Lateral Sclerosis (ALS) is a neurodegenerative disease that strongly impacts both patients' and caregivers' lives. Only few previous studies investigated the psychosocial impact of group's interventions on ALS patients and their caregivers as well as needs they can answer.

The aim was to identify the needs of both ALS patients and caregivers who attended a psychoeducational group program, the prominent aspects of their experience, perceptions, and satisfaction.

Methods: Five patients and thirteen caregivers attended eight psycho-educational group meetings at the Respiratory Rehabilitation Unit of Fondazione Don Carlo Gnocchi, Milan (Italy) and underwent semistructured interviews once the group meetings ended. Data obtained by group sessions' transcripts have been analysed using the Grounded Theory Paradigm (GT), while those obtained by interviews have been analysed using the Interpretative Phenomenological Analysis (IPA).

Results: The analysis of the meetings, allowed to identify seven themes and 21 sub-themes: practical advices, explanation of the pathology, recognition of emotions, adaptation, family and relationships, being caregiver of oneself and sharing. The analysis of the interviews allowed to deduce the main reasons to participate (i.e. to have information and to be able to share experiences), the positive and negative aspects of the experiences.

Conclusions: These results suggested the usefulness of psycho-educational groups into the regular clinical practice to allow patients and caregivers comparison with others in the same situation.

\section{Background}

Amyotrophic Lateral Sclerosis (ALS) is a neurodegenerative disease with unknown aetiology characterized by the progressive loss of lower and upper motor neurons (Chiò, Benzi, Dossena, Mutani, \& Mora, 2005; Zarei et al., 2015). There are currently no effective disease-modifying therapies, management is symptomatic; death often occurs in 3 to 5 years from the onset (Brown \& AlChalabi, 2017; Chiò et al., 2009; Mitchell \& Borasio, 2007; Zarei et al., 2015). Care delivered by multidisciplinary team has been showed to better address the complex needs of patients (Hogden, Foley, Henderson, \& James, 2017). Informal caregivers play a fundamental role in the ALS management, taking most of the responsibility (Aoun, Connors, Priddis, Breen, \& Colyer, 2015; Cipolletta \& Amicucci, 2015; De Wit et al., 2020).

Although there is limited information on the efficacy of group interventions, previous studies suggest the potentially positive impact of group interventions in people who is facing chronic diseases (Jensen et al., 2013; Kirk \& Milnes, 2016; Macdonald \& Greggans, 2010; Meade, Buchanan, \& Coulson, 2017; Parkyn \& Coveney, 2011). Previous studies had analysed psychological group intervention, providing some information regarding coping strategies used by people facing ALS and their caregivers (Cipolletta, Gammino, Francescon, \& Palmieri, 2018; Locock \& Brown, 2010; Madsen, Jeppesen, \& Handberg, 2018). In particular, Madsen et al. (2018), analysed a group rehabilitation therapy for ALS people, detecting an 
increased understanding of the disease and a sense of community, useful to fight together against ALS (Madsen et al., 2018). In their research, Locock and Brown (2010) found that, attending a support group, individuals gained both practical and social support, as well as opportunities for social comparison (Locock \& Brown, 2010). Finally, the first study that analysed support group participation in Italy has been conducted by Cipolletta et al. (2018), showing that caregivers' experience is different for partners or children and that they had the opportunity to express feeling and experiences without being judged from others (Cipolletta et al., 2018).

As showed by De Wit et al. (2020), a support intervention which contains psychoeducation, mindfulness exercises and practical information could be helpful for family caregivers of people with ALS (De Wit et al., 2020)

Despite the contributions illustrated above, there is a lack of studies that examined the impact of psychoeducational groups for people with ALS and their caregivers as well as the needs they can answer during this experience. Such theory-based studies may help facilitate standardized psychoeducational intervention efforts tailored to the development of enhanced both psychological and quality of life outcomes.

The aim of the current study was to describe the development and initial implementation of a structured psychoeducational intervention in ALS, identifying the needs of both patients and their caregivers. We report preliminary results on patients and caregiver perceptions of the psychoeducational intervention's relevance to their lives and satisfaction about their attendance.

\section{Methods}

\section{Study design}

A qualitative descriptive design was used (Glaser \& Strauss, 1967; Pietkiewicz, Smith, Pietkiewicz, \& Smith, 2014). The study was approved by the Ethics Committee of IRCCS Fondazione Don Carlo Gnocchi of Comitato Etico Regione Lombardia, Milan (Italy) on 21th June 2018.

\section{Participants}

ALS patients and their informal caregivers attending the Respiratory Rehabilitation Unit of IRCCS Santa Maria Nascente of Fondazione Don Carlo Gnocchi, Milan (Italy), and the related outpatient clinic accesses, were recruited between June and November 2018.

They were approached by a research assistant (VAB) and provided with information about the research study. The psychoeducational program was advertised within the Unit and during the clinical appointments through verbal invitations, email and printed flyers. The opportunity to connect remotely via internet was given to patients and caregivers, but nobody accepted it. A psychological interview has been proposed to all the future participants in order to assess their suitability for participation; psychologists evaluated if there were the emotional and cognitive conditions to take part in the study as well as if 
inclusion criteria were met (see Inclusion criteria). Participants choose which daily meeting take part to at their convenience (Monday or Friday meetings) and two groups have been created. Participants who expressed an interest in participating were given an information sheet, and contacted by phone to answer any queries, confirm agreement to participate and to arrange the interview. Informed written consent was obtained from all participants at the time of interview.

\section{Inclusion criteria}

\section{Inclusion criteria for patients}

a. Definite diagnosis of ALS according to El Escorial's criteria (Brooks, Miller, Swash, \& Munsat, 2000);

b. Having received the diagnosis for at least three months;

c. Being able to understand and to communicate what happens;

d. ECAS (Edinburgh Cognitive and Behavioural Amyotrophic Lateral Sclerosis Screening) $>105$ (Siciliano, Trojano, Trojsi, Greco, \& Santangelo, 2017);

e. Absence of Frontotemporal Dementia (FTD).

\section{Inclusion criteria for caregivers}
a. Caregiver of a person with ALS;
b. Between 18 and 85 years old;
c. MMSE > 24 (Measso et al., 1993).

\section{Procedure}

\section{Time and Setting}

Between December 2018 and July 2019 two psycho-educational groups for people with ALS and their caregivers were conducted at the Respiratory Rehabilitation Unit of the IRCCS Santa Maria Nascente of Fondazione Don Carlo Gnocchi, in Milan (Italy). Each group met for a total of nine monthly sessions, of one hour and half/ two hours each.

\section{Psychoeducation program}

A psychoeducation program was developed and delivered by two psychologists at the Unit mentioned above, characterized by specialty trained staff, therapeutic programming, and specific family involvement. The program was facilitated monthly on-site by a psychologist (EV) and a professional of the multidisciplinary team. A program logic model which illustrates the linear flow, the involved professionals, priorities and topics is shown in Table 1. 
Table 1

Group meetings

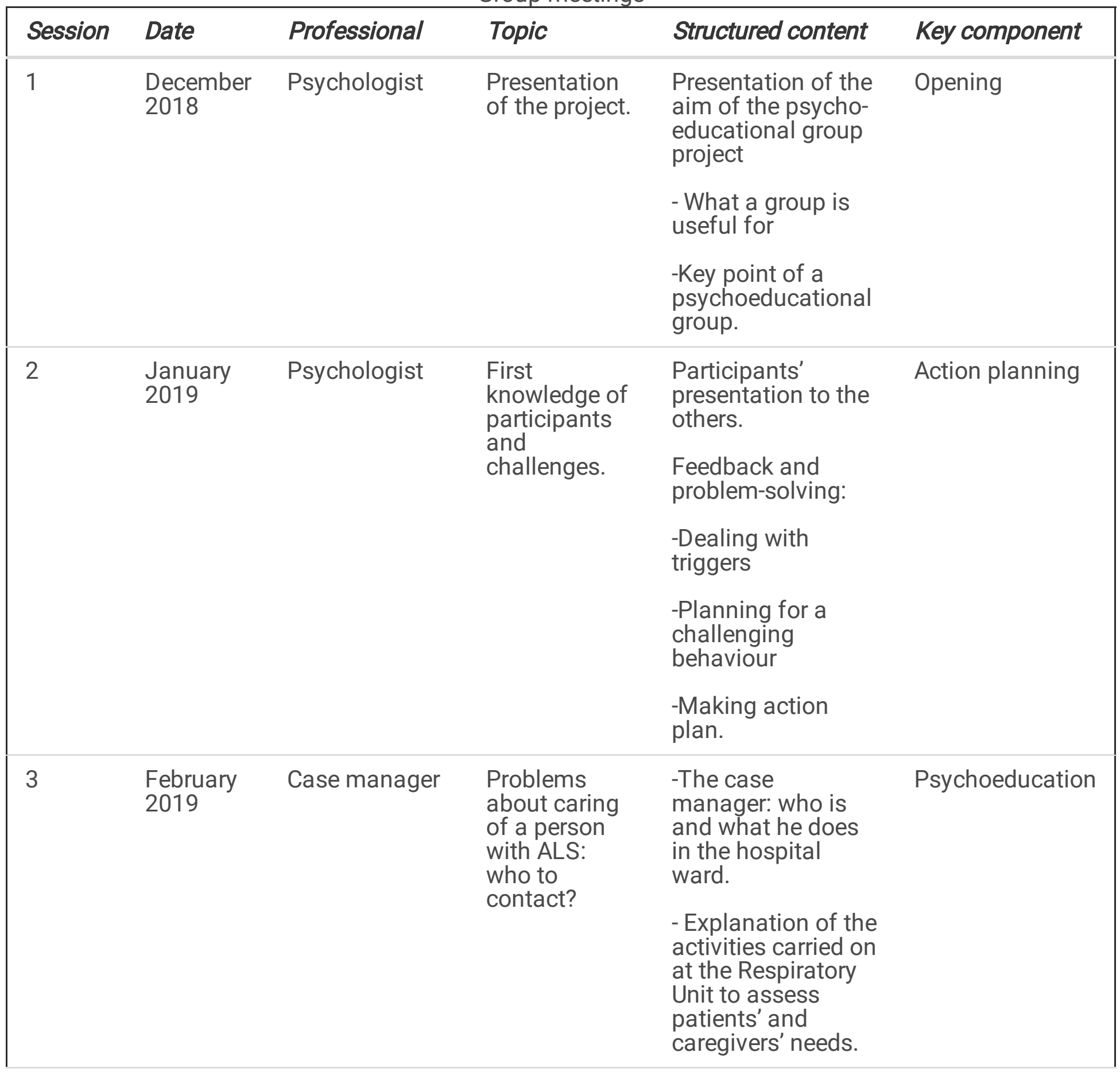




\begin{tabular}{|c|c|c|c|c|c|}
\hline Session & Date & Professional & Topic & Structured content & Key component \\
\hline \multirow[t]{4}{*}{4} & \multirow[t]{4}{*}{$\begin{array}{l}\text { March } \\
2019\end{array}$} & \multirow[t]{4}{*}{ Psychologist } & \multirow[t]{4}{*}{$\begin{array}{l}\text { Sharing } \\
\text { emotions }\end{array}$} & $\begin{array}{l}\text { Problem solving: } \\
\text {-Care partner's } \\
\text { challenging } \\
\text { behaviour: making } \\
\text { decisions }\end{array}$ & \multirow[t]{4}{*}{$\begin{array}{l}\text { Behavioural } \\
\text { intervention }\end{array}$} \\
\hline & & & & -Getting help & \\
\hline & & & & $\begin{array}{l}\text {-Stopping } \\
\text { unhelpful thinking }\end{array}$ & \\
\hline & & & & $\begin{array}{l}\text {-Making an action } \\
\text { plan }\end{array}$ & \\
\hline 5 & $\begin{array}{l}\text { April } \\
2019\end{array}$ & Pulmonologist & $\begin{array}{l}\text { Respiratory } \\
\text { and motor } \\
\text { problems } \\
\text { common in } \\
\text { ALS }\end{array}$ & $\begin{array}{l}\text { Education and } \\
\text { advices regarding } \\
\text { patients' difficulties } \\
\text { linked to the } \\
\text { respiratory } \\
\text { function. }\end{array}$ & Psychoeducation \\
\hline 6 & May 2019 & $\begin{array}{l}\text { Respiratory } \\
\text { physiotherapist }\end{array}$ & $\begin{array}{l}\text { Use of } \\
\text { physiotherapy } \\
\text { tools }\end{array}$ & $\begin{array}{l}\text { Explanation of the } \\
\text { main } \\
\text { physiotherapy } \\
\text { respiratory tools: } \\
\text { non-invasive } \\
\text { ventilation (NIV) } \\
\text { and cough } \\
\text { machine. }\end{array}$ & Psychoeducation \\
\hline \multirow[t]{5}{*}{7} & \multirow[t]{5}{*}{ May 2019} & \multirow[t]{5}{*}{ Nurse } & \multirow[t]{5}{*}{ Home care } & $\begin{array}{l}\text { Orientation to the } \\
\text { home care } \\
\text { situation: }\end{array}$ & \multirow[t]{5}{*}{ Psychoeducation } \\
\hline & & & & -Helpful thinking; & \\
\hline & & & & -Medication usage; & \\
\hline & & & & $\begin{array}{l}\text { - Finding and hiring } \\
\text { help; }\end{array}$ & \\
\hline & & & & $\begin{array}{l}\text {-Future planning } \\
\text { and legal issues. }\end{array}$ & \\
\hline 8 & $\begin{array}{l}\text { June } \\
2019\end{array}$ & Psychologist & $\begin{array}{l}\text { Meeting } \\
\text { stress }\end{array}$ & $\begin{array}{l}\text { Orientation to the } \\
\text { full stress reaction } \\
\text { and physical, } \\
\text { emotional and } \\
\text { cognitive sequelae; } \\
\text { education } \\
\text { regarding enduring } \\
\text { and chronic stress } \\
\text { models. }\end{array}$ & Modelling \\
\hline
\end{tabular}




\begin{tabular}{|c|c|c|c|c|c|}
\hline Session & Date & Professional & Topic & Structured content & Key component \\
\hline 9 & July 2019 & Psychologist & $\begin{array}{l}\text { The end of } \\
\text { the journey: } \\
\text { what will we } \\
\text { bring at } \\
\text { home? }\end{array}$ & $\begin{array}{l}\text { Reviewing difficult } \\
\text { care partner } \\
\text { emotions; working } \\
\text { with } \\
\text { systems/providers; } \\
\text { communication } \\
\text { skills; looking back } \\
\text { and planning for } \\
\text { the future; closing. }\end{array}$ & Conclusion \\
\hline
\end{tabular}

Program aims were improving emotional well-being; increasing peer support and awareness; increasing knowledge and information about the illness and its challenges.

\section{Data collection}

Demographic data were collected to describe the sample. Each group session was audio-recorded and transcribed verbatim, then these transcripts have been used to investigate participants' needs. Observations and points of relevant information during and after the sessions filled in field notes. Moreover, a semi-structured and iterative interview guide was used at the end of the program to explore perceptions and satisfaction of joint attendance (Table 2). Field notes completed and prompted questions for future developments. Interviews lasted approximately 15 minutes, were conducted by a research assistant (VAB) thanks to a phone call, audiotaped and transcribed verbatim.

Table 2

Guide interview

\section{Questions}

1) Why did you choose to participate to psycho-educational groups' meetings?

Why did you choose to interrupt groups 'participation?

2) Which elements of groups' participation did you find positive?

And which elements did you find negative?

3) Which advices would you suggest improving the psycho-educational groups 'experience?

4) Are you satisfied with groups' participation?

\section{Data analysis}

Descriptive statistical analyses were performed using SPSS Version 24.0 to summarise the demographic and clinical data, characteristics of the caregivers and patients.

Qualitative data were analysed using NVivo software (Version 12, QSR International $\rightarrow$ ). 
Analysis of transcripts data considered both the group meetings and the semi-structured interviews: the two transcripts have been separately analysed in order to achieve the two different aims.

Data from sessions were analysed using dimensional analysis and constant comparative method, which are designed to be used with text in Grounded Theory (Corbin \& Strauss, 2014; Glaser \& Strauss, 1967). These strategies allow the two researchers (EV; VAB) to independently identify both implicit and explicit dimensions of relevant needs and concepts. Data were coded using open, axial and theoretical coding strategies (Charmaz, 2006). The comparative method allowed to detect similarities and differences in the levels of analysis (Glaser \& Strauss, 1967).

Analysis of the semi-structured interviews followed Interpretative Phenomenological Analysis (IPA) in order to better understand patients' and caregivers' experiences and perceptions of the program (Pietkiewicz et al., 2014). Each interview was read several times to gain an overall impression of it. Researchers made notes in margins about the content and the language used by the interviewed. Phrases, key words and idiosyncratic feature of speech were highlighted. On re-reading the interviews notes have been transformed in themes and sub-themes. Finally, the themes obtained were ordered in a table.

Content analysis of audio recordings, process notes and exit interviews were conducted for triangulation. Discrepancies in theme categorization and coding were addressed by a third researcher (FP) in both the GT and IPA analysis.

\section{Results}

\section{Characteristics of sample}

Thirty patients and caregivers were approached and assessed to take part to the study: 9 refused to participate, 3 have been excluded due to cognitive impairment $(E C A S<105)$ and 18 joined group's attendance. The sample included 5 ALS patients (Table 3 ) (one had a bulbar onset, one a respiratory one and three a lumbar onset) and 13 caregivers (Table 4) (7 were partners and 6 children of the patients with ALS). 
Table 3

Patients' characteristics

\begin{tabular}{|ll|}
\hline Demographics characteristics & Patient $(\mathbf{n}=\mathbf{5})$ \\
\hline Age & $67.2(11.16)$ \\
Mean (SD) & \\
Gender & \\
Male & 3 \\
Female & 2 \\
\hline Months since diagnosis & $20.4(21.6)$ \\
Mean (SD) & \\
Tracheostomy & 1 \\
PEG & 1 \\
ALSFRS-R & $42.47(3.71)$ \\
Mean (SD) & \\
\hline
\end{tabular}

Table 4

Caregivers' characteristics

\begin{tabular}{|ll|}
\hline Demographics characteristics & Caregivers $(\mathbf{n}=13)$ \\
\hline Age & \\
Mean (SD) & $61.38(14.35)$ \\
Gender & \\
Male & 5 \\
Female & 8 \\
\hline
\end{tabular}

\section{Themes and Sub-themes emerged from transcripts}

The main findings emerged from the psychoeducational program sessions were organized into 7 key themes and 21 sub-themes (Table 5). The key themes represent the need expressed by participants, among which the need for practical advices and the need for an explanation of the pathology were the most frequent. Table 5 also shows the most frequently used words and the percentage of covered text for each theme. 
Table 5

Themes and Sub-themes emerged from groups 'analysis

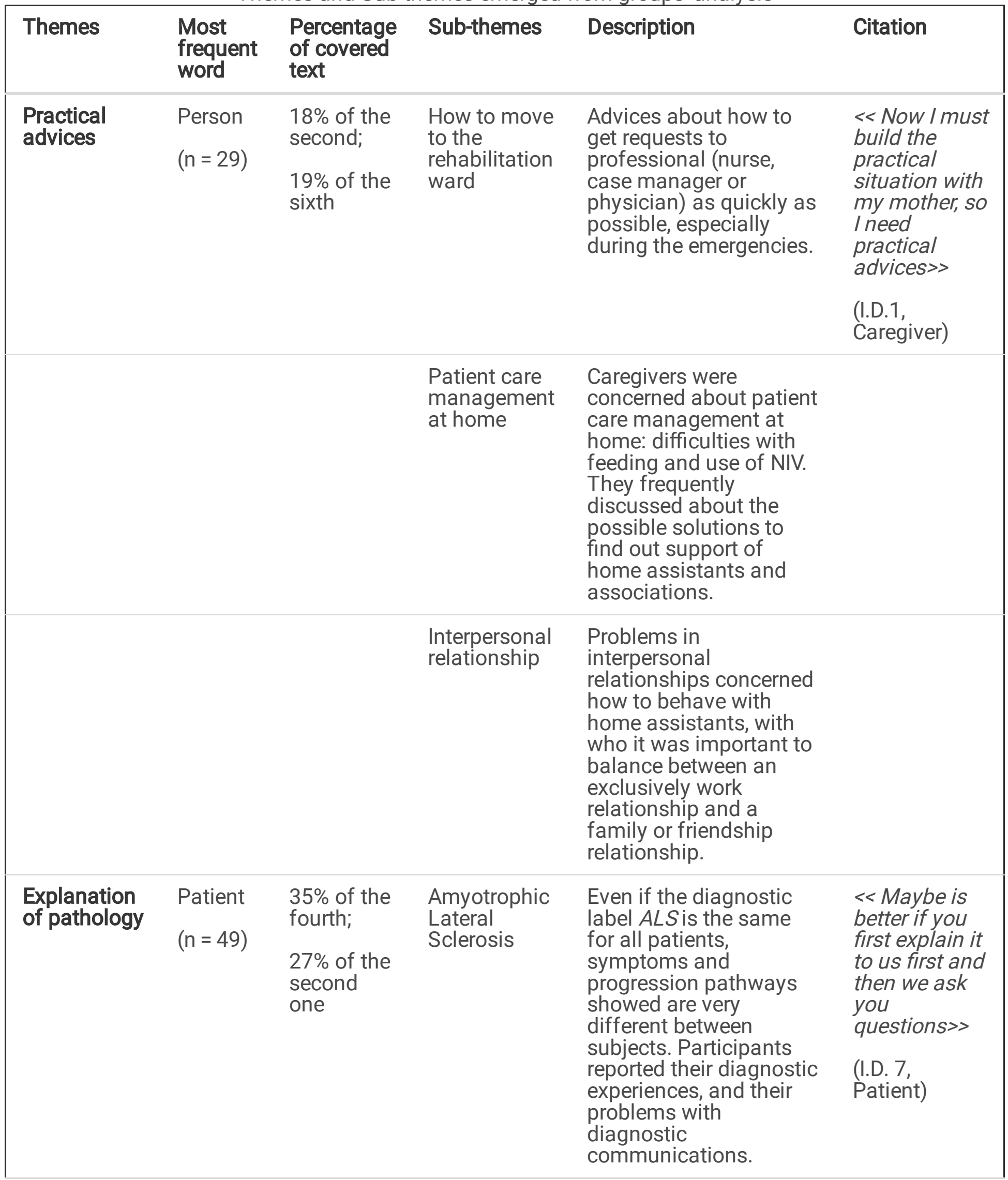




\begin{tabular}{|c|c|c|c|c|c|}
\hline Themes & $\begin{array}{l}\text { Most } \\
\text { frequent } \\
\text { word }\end{array}$ & $\begin{array}{l}\text { Percentage } \\
\text { of covered } \\
\text { text }\end{array}$ & Sub-themes & Description & Citation \\
\hline & & & $\begin{array}{l}\text { Taking care } \\
\text { of the patient }\end{array}$ & $\begin{array}{l}\text { Each of the } \\
\text { professionals who took } \\
\text { part to group meetings } \\
\text { explained which his role } \\
\text { within the } \\
\text { multidisciplinary team } \\
\text { was. Participants } \\
\text { appreciated the issues } \\
\text { about humanization of } \\
\text { care, feeling considered } \\
\text { as people and respected } \\
\text { in their dignity. }\end{array}$ & \\
\hline & & & $\begin{array}{l}\text { Equipment } \\
\text { and } \\
\text { economics } \\
\text { help }\end{array}$ & $\begin{array}{l}\text { Economic measures } \\
\text { and the helps made } \\
\text { available from the } \\
\text { Italian State or Regions } \\
\text { to help patients with } \\
\text { ALS and their } \\
\text { caregivers. }\end{array}$ & \\
\hline & & & $\begin{array}{l}\text { Emotions } \\
\text { linked to ALS }\end{array}$ & $\begin{array}{l}\text { Education about the } \\
\text { emotional components } \\
\text { linked to ALS: } \\
\text { participants have been } \\
\text { invited to make a } \\
\text { distinction between } \\
\text { emotions and thoughts. }\end{array}$ & \\
\hline
\end{tabular}




\begin{tabular}{|c|c|c|c|c|c|}
\hline Themes & $\begin{array}{l}\text { Most } \\
\text { frequent } \\
\text { word }\end{array}$ & $\begin{array}{l}\text { Percentage } \\
\text { of covered } \\
\text { text }\end{array}$ & Sub-themes & Description & Citation \\
\hline \multirow[t]{2}{*}{$\begin{array}{l}\text { Recognition } \\
\text { of emotions }\end{array}$} & $\begin{array}{l}\text { Fear } \\
(n=9)\end{array}$ & $\begin{array}{l}6 \% \text { of the } \\
\text { third; } \\
7 \% \text { of the } \\
\text { seventh }\end{array}$ & $\begin{array}{l}\text { Most } \\
\text { frequent } \\
\text { emotions }\end{array}$ & $\begin{array}{l}\text { Fear was referred by } \\
\text { patients who often } \\
\text { linked it to the inability } \\
\text { to control the disease } \\
\text { progression, and } \\
\text { caregivers' burden (they } \\
\text { were scared about the } \\
\text { idea that they could } \\
\text { compromise caregivers' } \\
\text { physical or } \\
\text { psychological health). } \\
\text { Anger was often linked } \\
\text { to the ALS and his } \\
\text { progression by both } \\
\text { patients and caregivers. } \\
\text { Some caregivers (n= } 3 \text { ) } \\
\text { referred that they were } \\
\text { often angry with the } \\
\text { patient they care for; } \\
\text { other caregivers (n = 4) } \\
\text { referred that they are } \\
\text { not. In the first case, } \\
\text { caregivers often linked } \\
\text { angry to guilt because } \\
\text { they recognized that } \\
\text { patients have no blame } \\
\text { in their own condition. } \\
\text { Sadness was very } \\
\text { common for patients } \\
\text { who saw their body } \\
\text { deteriorating. Caregivers } \\
\text { felt patients' sadness } \\
\text { and they often tried to } \\
\text { console him, even if this } \\
\text { was very difficult. } \\
\text { Shame was often linked } \\
\text { to the worsening of } \\
\text { patient's health } \\
\text { condition. }\end{array}$ & $\begin{array}{l}<<\text { Emotionally } \\
\text { it is } \\
\text { exhausting >> } \\
\text { (I.D. 3, } \\
\text { Caregiver) }\end{array}$ \\
\hline & & & $\begin{array}{l}\text { Legitimize } \\
\text { emotions }\end{array}$ & $\begin{array}{l}\text { A difficulty to accept } \\
\text { emotions was common } \\
\text { between participants. } \\
\text { This made it easier to } \\
\text { legitimize this difficulty } \\
\text { and negative emotions } \\
\text { as normal issues. }\end{array}$ & \\
\hline
\end{tabular}




\begin{tabular}{|c|c|c|c|c|c|}
\hline Themes & $\begin{array}{l}\text { Most } \\
\text { frequent } \\
\text { word }\end{array}$ & $\begin{array}{l}\text { Percentage } \\
\text { of covered } \\
\text { text }\end{array}$ & Sub-themes & Description & Citation \\
\hline \multirow[t]{3}{*}{ Adaptation } & $\begin{array}{l}\text { Disease } \\
(n=35)\end{array}$ & $\begin{array}{l}9,5 \% \text { of the } \\
\text { fifth; } \\
9 \% \text { of the } \\
\text { first }\end{array}$ & $\begin{array}{l}\text { Acceptance } \\
\text { of the } \\
\text { pathology }\end{array}$ & $\begin{array}{l}\text { Participants often } \\
\text { referred that was not } \\
\text { easy to accept this } \\
\text { illness. Psychologists } \\
\text { often invited patients } \\
\text { and caregivers to focus } \\
\text { on the difference } \\
\text { between acceptance } \\
\text { and adaptation. It is } \\
\text { impossible to accept } \\
\text { ALS, the only thing you } \\
\text { can do is to adapt to. }\end{array}$ & $\begin{array}{l}<<\text { I don't } \\
\text { accept my } \\
\text { illness. }>> \\
\text { (I.D. 2, } \\
\text { Patient) }\end{array}$ \\
\hline & & & $\begin{array}{l}\text { Elaboration } \\
\text { of a loss }\end{array}$ & $\begin{array}{l}\text { Participants often } \\
\text { expressed a difficulty in } \\
\text { accepting the loss of } \\
\text { their daily routine, as it } \\
\text { was before the onset of } \\
\text { ALS. It was very difficult } \\
\text { to accept that it is no } \\
\text { longer possible to walk } \\
\text { on your own legs or eat } \\
\text { everything you want to. } \\
\text { Caregivers instead } \\
\text { referred that it was a } \\
\text { problem to empathize } \\
\text { with patient's feeling } \\
\text { about loss of } \\
\text { functionality. Caregiver } \\
\text { often used negation as } \\
\text { defence mechanism. }\end{array}$ & \\
\hline & & & $\begin{array}{l}\text { How to fight } \\
\text { ALS }\end{array}$ & $\begin{array}{l}\text { Everyone finds his own } \\
\text { strategies: some cited } \\
\text { living day by day as a } \\
\text { good strategy; it } \\
\text { consists on content of } \\
\text { what it is still possible, } \\
\text { of the activity patients } \\
\text { can still perform without } \\
\text { worries about patient's } \\
\text { worsening; other used } \\
\text { isolation as a strategy } \\
\text { to face the challenges } \\
\text { posed by ALS. }\end{array}$ & \\
\hline
\end{tabular}




\begin{tabular}{|c|c|c|c|c|c|}
\hline Themes & $\begin{array}{l}\text { Most } \\
\text { frequent } \\
\text { word }\end{array}$ & $\begin{array}{l}\text { Percentage } \\
\text { of covered } \\
\text { text }\end{array}$ & Sub-themes & Description & Citation \\
\hline \multirow[t]{3}{*}{$\begin{array}{l}\text { Family and } \\
\text { relationships }\end{array}$} & $\begin{array}{l}\text { Brother } \\
(n=28)\end{array}$ & $\begin{array}{l}13,5 \% \text { of } \\
\text { third; } \\
12,5 \% \text { of } \\
\text { the } \\
\text { seventh }\end{array}$ & Family & $\begin{array}{l}\text { In some families }(n=3) \text {, } \\
\text { the duty of care was } \\
\text { equally divided between } \\
\text { caregivers; in these } \\
\text { families, relationships } \\
\text { were better, and no } \\
\text { family member felt } \\
\text { alone in the fight } \\
\text { against ALS. In other } \\
\text { cases ( } n=2) \text {, this } \\
\text { division of tasks was } \\
\text { not possible, and it } \\
\text { created pain and suffer } \\
\text { among family members. } \\
\text { It seems that care of the } \\
\text { seek family member has } \\
\text { awaked an old pain an } \\
\text { old rancour in these } \\
\text { families. }\end{array}$ & $\begin{array}{l}\ll \text { Thanks to } \\
\text { the disease I } \\
\text { have seen } \\
\text { who a friend } \\
\text { is and who is } \\
\text { not. Many got } \\
\text { away, both } \\
\text { relatives and } \\
\text { friends.>> } \\
\text { (I.D. 2, } \\
\text { Patient) }\end{array}$ \\
\hline & & & Friendship & $\begin{array}{l}\text { After the onset of ALS } \\
\text { also friendly } \\
\text { relationships changed. } \\
\text { Some }(n=3) \text { reported } \\
\text { that they have friends } \\
\text { who take care of the } \\
\text { patient, trying to } \\
\text { encourage him. Others } \\
(n=4) \text { referred a loss of } \\
\text { friends after the onset } \\
\text { of ALS; this was often } \\
\text { reported sadly by } \\
\text { participants and linked } \\
\text { to the friends' difficulty } \\
\text { in accepting patients' } \\
\text { illness and patients' loss } \\
\text { of functionality. }\end{array}$ & \\
\hline & & & $\begin{array}{l}\text { Loneliness } \\
\text { and choice } \\
\text { of isolation }\end{array}$ & $\begin{array}{l}\text { For some }(n=4) \\
\text { loneliness was an } \\
\text { uncomfortable } \\
\text { condition; experienced } \\
\text { as something negative } \\
\text { and it seemed that there } \\
\text { was no one to count on. } \\
\text { Others }(n=4) \text { told about } \\
\text { loneliness as something } \\
\text { chose to protect } \\
\text { themselves from the } \\
\text { reactions that other } \\
\text { people might show; } \\
\text { isolation seems to be } \\
\text { functional to protect } \\
\text { against the feeling of } \\
\text { shame. }\end{array}$ & \\
\hline
\end{tabular}




\begin{tabular}{|c|c|c|c|c|c|}
\hline Themes & $\begin{array}{l}\text { Most } \\
\text { frequent } \\
\text { word }\end{array}$ & $\begin{array}{l}\text { Percentage } \\
\text { of covered } \\
\text { text }\end{array}$ & Sub-themes & Description & Citation \\
\hline & & & $\begin{array}{l}\text { Exit from } \\
\text { home }\end{array}$ & $\begin{array}{l}\text { Caregivers often } \\
\text { complained about } \\
\text { patients who do not } \\
\text { want to leave their } \\
\text { houses. The group was } \\
\text { useful to show how } \\
\text { similar this difficulty } \\
\text { was present in many } \\
\text { patients and to } \\
\text { normalize the situation. }\end{array}$ & \\
\hline \multirow[t]{2}{*}{$\begin{array}{l}\text { Being } \\
\text { caregiver of } \\
\text { oneself }\end{array}$} & $\begin{array}{l}\text { Must } \\
(n=10)\end{array}$ & $\begin{array}{l}4 \% \text { of the } \\
\text { first; } \\
4 \% \text { of the } \\
\text { third }\end{array}$ & $\begin{array}{l}\text { Need to } \\
\text { protect } \\
\text { oneself and } \\
\text { to find time } \\
\text { for oneself }\end{array}$ & $\begin{array}{l}\text { Caregivers often } \\
\text { showed the need to } \\
\text { protect their } \\
\text { psychological world } \\
\text { from a situation } \\
\text { perceived as damaging } \\
\text { for their own physical } \\
\text { and psychological } \\
\text { health. They reported a } \\
\text { severe difficulty in } \\
\text { taking time for } \\
\text { themselves, as if they } \\
\text { were stealing this time } \\
\text { from patient care. }\end{array}$ & $\begin{array}{l}\text { < It is } \\
\text { important to } \\
\text { protect } \\
\text { yourself. It is } \\
\text { important to } \\
\text { have the } \\
\text { opportunity to } \\
\text { take care of } \\
\text { yourself. You } \\
\text { cannot delate } \\
\text { yourself. } \gg \\
\text { (I.D. 20, } \\
\text { Psychologist) }\end{array}$ \\
\hline & & & Duty of care & $\begin{array}{l}\text { Caregivers often felt } \\
\text { obliged to spend time, } \\
\text { which could be spent on } \\
\text { self-care, with the } \\
\text { patient. Then, when they } \\
\text { finally succeeded in } \\
\text { having time for } \\
\text { themselves, guilt took } \\
\text { over. }\end{array}$ & \\
\hline Sharing & $\begin{array}{l}\text { Group } \\
(n=33)\end{array}$ & $\begin{array}{l}14 \% \text { of the } \\
\text { third; } \\
10 \% \text { the } \\
\text { sixth one }\end{array}$ & $\begin{array}{l}\text { Sharing } \\
\text { patient care }\end{array}$ & $\begin{array}{l}\text { Since it was impossible } \\
\text { to survive with the } \\
\text { burden of patient care, } \\
\text { many }(n=5) \text { caregivers } \\
\text { reported a need of } \\
\text { sharing care with others. } \\
\text { Group has been } \\
\text { recognized as a safe } \\
\text { place where it was } \\
\text { possible to ask for helps } \\
\text { and to receive it, feeling } \\
\text { less isolated in the } \\
\text { caring process. }\end{array}$ & $\begin{array}{l}\text { e<If I hadn't } \\
\text { had the } \\
\text { opportunity to } \\
\text { confront with } \\
\text { people who } \\
\text { live my same } \\
\text { situation and } \\
\text { to share with } \\
\text { them, maybe I } \\
\text { would have } \\
\text { gone out of } \\
\text { my mind!>> } \\
\text { (I.D. 1, } \\
\text { Caregiver) }\end{array}$ \\
\hline
\end{tabular}




\begin{tabular}{|c|c|c|c|c|c|}
\hline Themes & $\begin{array}{l}\text { Most } \\
\text { frequent } \\
\text { word }\end{array}$ & $\begin{array}{l}\text { Percentage } \\
\text { of covered } \\
\text { text }\end{array}$ & Sub-themes & Description & Citation \\
\hline & & & $\begin{array}{l}\text { Sharing life } \\
\text { experiences } \\
\text { and } \\
\text { difficulties }\end{array}$ & $\begin{array}{l}\text { Participants often } \\
\text { described life } \\
\text { experiences, reporting } \\
\text { experiences about the } \\
\text { diagnostic process and } \\
\text { the difficulties with } \\
\text { diagnostic } \\
\text { communication, with } \\
\text { the adaptation to the } \\
\text { disease and with the } \\
\text { use of some tools as } \\
\text { NIV. }\end{array}$ & \\
\hline & & & $\begin{array}{l}\text { Sharing as } \\
\text { an } \\
\text { opportunity }\end{array}$ & $\begin{array}{l}\text { Participants understood } \\
\text { that they were not alone } \\
\text { in this situation. In this } \\
\text { process, a kay point was } \\
\text { the help of } \\
\text { professionals who gave } \\
\text { information and advices } \\
\text { to better cope with the } \\
\text { ALS. They made } \\
\text { participants feel less } \\
\text { alone and more } \\
\text { supported. }\end{array}$ & \\
\hline
\end{tabular}

Connections between themes also emerged. First, the themes Recognition of emotions and Family and Relationships were both most present in the third and the seventh group meetings; it also emerges that the emotional theme and the relational theme are present together in meetings one, two, three, five, six, seven and eight; while Family and Relationships is present alone in the fourth meeting. That could suggest a link between the two themes (Fig. 1). Secondly, caregivers often linked the theme Being caregiver of oneself to the relational one, because they find it extremely difficult to maintain their own relationships after the onset of ALS in their relative, this connection is shown in Fig. 2.

\section{Themes and Sub-themes emerged from semi-structed interviews}

Interviews' analysis allowed to understand participants' perceptions and satisfaction about group meetings. The 3 themes and 4 sub-themes emerged form analyses are shown in Table 6 . The emerged themes concerned the reasons why patients and caregivers took part in the psychoeducation program and the positive/negative aspects of participation. Moreover, participants generally felt satisfied with group's attendance and expressed appreciation for this activity. Some $(n=6)$ also expressed the will to carry on group meetings. 
Table 6

Themes and sub-themes emerged from interviews

\begin{tabular}{|c|c|c|c|}
\hline Theme & $\begin{array}{l}\text { Percentage } \\
\text { of covered } \\
\text { text }\end{array}$ & Sub-themes & Description \\
\hline \multirow{6}{*}{$\begin{array}{l}\text { Reason for the } \\
\text { choice to } \\
\text { participate/leave } \\
\text { the group }\end{array}$} & \multirow[t]{6}{*}{$20 \%$} & \multirow[t]{5}{*}{$\begin{array}{l}\text { Reason for } \\
\text { participating }\end{array}$} & $\begin{array}{l}\text { - Seek information about the disease and the } \\
\text { disease progression or about patient care }(n=6) \text {; }\end{array}$ \\
\hline & & & $\begin{array}{l}\text { - Confront with others who are all in the same } \\
\text { situation }(n=3)\end{array}$ \\
\hline & & & $\begin{array}{l}\text { - Desire for a comfortable place to share emotions } \\
\text { and difficulties }(n=2) \text {; }\end{array}$ \\
\hline & & & $\begin{array}{l}\text { - Share a route with the patient they care for }(n= \\
2) ;\end{array}$ \\
\hline & & & $\begin{array}{l}\text { - Need of a place to be listened to without being } \\
\text { judged }(n=2) \text {. }\end{array}$ \\
\hline & & $\begin{array}{l}\text { Reasons for } \\
\text { leaving }\end{array}$ & $\begin{array}{l}\text { The reasons why participants have left group's } \\
\text { attendance could only be asked in one single case. } \\
\text { This person referred that she was forced to } \\
\text { interrupt group's attendance because of an } \\
\text { extremely negative emotional reaction after the } \\
\text { first two group meetings and because of the } \\
\text { worries about what other participants could think } \\
\text { listening her stories about her husband's disease } \\
\text { (this patient was in a severe ALS condition, more } \\
\text { severe than the other participants' one). }\end{array}$ \\
\hline \multirow[t]{5}{*}{$\begin{array}{l}\text { Positive and } \\
\text { negative aspects }\end{array}$} & \multirow[t]{5}{*}{$27 \%$} & \multirow[t]{3}{*}{$\begin{array}{l}\text { Positive } \\
\text { aspects }\end{array}$} & $\begin{array}{l}\text { - Opportunity of sharing and of support that the } \\
\text { group can provide; }\end{array}$ \\
\hline & & & $\begin{array}{l}\text { - The big amount of information shared in the } \\
\text { group; }\end{array}$ \\
\hline & & & $\begin{array}{l}\text { - The group could be a reference point, that can } \\
\text { help in facing difficulties. }\end{array}$ \\
\hline & & $\begin{array}{l}\text { Negative } \\
\text { aspects }\end{array}$ & $\begin{array}{l}\text { - The difficulty in participating in a group in which } \\
\text { levels of disease progression were different. Most } \\
\text { of the conversations, in fact, were about disease } \\
\text { progression and listen to this was very difficult for } \\
\text { patients at the first stage of ALS. Participants } \\
\text { often referred that they were distressed after group } \\
\text { meetings. }\end{array}$ \\
\hline & & & - The joint participation of patients and caregivers. \\
\hline
\end{tabular}




\begin{tabular}{|c|c|c|c|}
\hline Theme & $\begin{array}{l}\text { Percentage } \\
\text { of covered } \\
\text { text }\end{array}$ & Sub-themes & Description \\
\hline \multirow[t]{2}{*}{$\begin{array}{l}\text { Which advices } \\
\text { to improve? }\end{array}$} & $8 \%$ & & $\begin{array}{l}\text { - Participation of other professional figures that } \\
\text { could be important in ALS management, such as a } \\
\text { nutritionist and an otorhinolaryngologist which } \\
\text { could provide important information. }\end{array}$ \\
\hline & & & $\begin{array}{l}\text { - Restrict participation only to caregivers in order to } \\
\text { inform them about the disease and its progression } \\
\text { more in detail. }\end{array}$ \\
\hline
\end{tabular}

\section{Discussion}

The present study explored the needs emerged in psycho-educational groups for patient with ALS and their caregivers as well as their experiences of participation. Analysis of the group sessions and of the interviews showed that many participants chose to attend the groups to find information about their own illness or their caregiver's one, as also highlighted in previous studies (Madsen et al., 2018; Passoni et al., 2014). Having received information about ALS and ALS's progression was a crucial point, especially for caregivers, who referred to feel more confident and peaceful after group participation. Passoni et al. (2014) also highlighted this point, showing that when caregivers were sufficiently informed about their patient's illness, they felt less anxious. There was no previous literature on why participants leave groups for patients with ALS and/or for their caregivers; this was a new element proposed by the present study.

Practical advices was one of the emerged themes and one of the participants' most appreciated element, as Locock and Brown had previously showed (Locock \& Brown, 2010). Locock and Brown (2010) and Passoni (2014) highlighted the importance of sharing in a group composed by people that live a same situation. This theme emerged also in the present study both as a frequent topic in the transcripts and as a positive aspect reported in the interviews (Locock \& Brown, 2010; Passoni et al., 2014). Practical advices (18\% of covered text in session 2 and $19 \%$ in session 6 ), Explanation of pathology ( $35 \%$ of covered text in session 4 and $27 \%$ in session 2 ) and Sharing (14\% of cover text in session 3 and $10 \%$ in session 6) represented the most common topics participants told about; so, they probably were the basic themes, respect to which the others were consequent. Previous studies didn't analyse much the familiar and relational theme, which instead was analysed by the present study. Locock and Brown focused on Isolation as a choice made by patients with ALS to protect themselves from negative emotions, as shame. This theme also emerged from the analysed group sessions (Locock \& Brown, 2010). Moreover Cipolletta et al. (2018) analysed support groups for caregivers and found that caregivers often referred to patient care as a duty. The present study, which highlighted the Duty of care as a sub-theme, was coherent with this previous qualitative research (Cipolletta et al., 2018). Adaptation was the last important theme in this study. Previous literature about group interventions for people with ALS and/or their caregivers had analysed this theme. Marconi et al. (2016) showed that a meditation training for people with ALS and their caregivers improved their acceptance of the disease and the restrictions due to symptoms (Marconi et al., 2016). Later, Cipolletta et al. (2018) referred to the caregivers' acceptance of 
ALS; their groups were not organized for patients, so they didn't refer to patient adaptation to the illness (Cipolletta et al., 2018).

There were no studies in previous literature that investigated aspects that patients found negative in participating to group's sessions, nor about advices to improve the group's meetings.

\section{Strengths and limitations}

One of the most relevant strengths in this study was the novelty of the topic because there was no previous literature about psycho-educational group for people with ALS and their caregivers. Another positive element was the nature of the analysed data, which came both from transcripts of group meetings' sessions and from interviews. As regard interviews, their novelty was represented by questions about reason why participants decided to participate or to leave the group.

The main limitation of this study was the limited number of participants and the restricted geographic area from where they come from. It was not possible to interview all the participants, so we hadn't a feedback from all patients and caregivers. Having more data to compare would have made it possible to strengthen the conclusions.

\section{Future implications}

There is a need of further studies to better understand the experience of participation in groups for people with ALS and their caregivers. These studies might be conducted with a larger sample and in different geographic areas or using a quantitative research method. It could offer the possibility to make confronts between different times about important issues as anxiety, quality of life and caregivers' burden. It could be useful also administering a semi-structured interview before the beginning of the group's meetings to better understand participants' expectation. Last, future research might compare the different themes that could emerge in other types of groups for patient with ALS and/or their caregiver.

\section{Clinical and Research implications}

The intervention based on psycho-educational groups represents a possible help for patients and caregivers facing ALS. Perceived benefits support the use of the program as an intervention and identified challenges can be used to tailor it to improve inclusivity and manage group dynamics. Indeed, an intervention that keeps together the element of support and the element of multidisciplinary could be very useful in addressing the complex needs of ALS patients and their caregivers.

On the other hand, our knowledge about psycho-educational groups for people with ALS and their caregivers need to be expanded. This study showed the difficulties found in carrying on researches that involves participants who fight against a neurodegenerative illness. Future researches are essential to verify the efficacy of this type of intervention.

\section{Conclusions}


This study of psycho-educational groups for patients with ALS and their caregivers indicates the utility of this type of intervention in supporting people who fight against ALS for two main reasons: first for the element of psychoeducation provided by professional; second for the possibility of sharing experiences and emotions with people in the same situation.

\section{List Of Abbreviations}

Amyotrophic Lateral Sclerosis, ALS; non-invasive ventilation, NIV; Grounded Theory, GT; Interpretative Phenomenological Analysis, IPA; percutaneous endoscopic gastrostomy, PEG; Revised Amyotrophic Lateral Sclerosis Functional Rating Scale, ALSFRS-R; ID: Identifier (of the participant)

\section{Declarations}

\section{Ethics statement}

This study was conducted in accordance with the principles of Helsinki Declaration and approved by the Ethics Committee of IRCCS Fondazione Don Carlo Gnocchi of Comitato Etico Regione Lombardia, Milan (Italy) on $21^{\text {th }}$ June 2018. All the participants were informed that the meetings would be audio-recorded. If they accepted, they were invited to read and sing in the Consent Form for data collection and pseudonyms were used to preserve their anonymity.

\section{Consent for publication}

All the participants provided written informed consent for publication.

\section{Availability of data and materials}

The datasets generated during and/or analysed during the current study are available from the corresponding author on a reasonable request.

\section{Competing Interests}

The authors declare that they have not competing interests.

\section{Funding}

The authors received no specific funding for this work.

\section{Authors' contributions}

EV designed the study; VAB together with EV and FP analysed the data and interpretated the results. VAB and EV drafted the manuscript and FP and PIB critically revised it. All authors approved the final version of the manuscript, they are accountable for all aspects of the accuracy and integrity of the manuscript in accordance with ICMJE criteria. 


\section{Acknowledgments}

We would like to give special thanks to our participants who graciously gave their time to take part in this study.

We are also grateful to Agata Lax, Antonietta Vecera, Cecilia Vitucci, Chiara Valota and Salvatore D'Ascenzo for their suggestions and support across the psycho-educational groups.

\section{References}

1. Aoun, S. M., Connors, S., Priddis, L., Breen, L. J., \& Colyer, S. (2015). Motor Neurone Disease family carers ' experiences of caring, palliative care and bereavement: An exploratory qualitative study, 26(6), 842-850. https://doi.org/10.1177/0269216311416036

2. Brooks, B. R., Miller, R. G., Swash, M., \& Munsat, T. L. (2000). El Escorial revisited: Revised criteria for the diagnosis of amyotrophic lateral sclerosis. Amyotrophic Lateral Sclerosis, 1(5), 293-299. https://doi.org/10.1080/146608200300079536

3. Brown, R. H., \& AlChalabi, A. (2017). Amyotrophic Lateral Sclerosis. The New England Journal of Medicine, 377,2. https://doi.org/10.1056/NEJMra1603471

4. Charmaz K. (2006). Constructing Grounded Theory: A Practical Guide through Qualitative Analysi. SAGE Publications, Thousand Oaks, CA

5. Chiò, A., Benzi, G., Dossena, M., Mutani, R., \& Mora, G. (2005). Severely increased risk of amyotrophic lateral sclerosis among Italian professional football players. Brain, 128(3), 472-476. https://doi.org/10.1093/brain/awh373

6. Chiò, A., Logroscino, G., Hardiman, O., Swingler, R., Mitchell, D., Beghi, E., \& Traynor, B. G. (2009). Prognostic factors in ALS: A critical review. Amyotrophic Lateral Sclerosis, 10(5-6), 310-323. https://doi.org/10.3109/17482960802566824

7. Cipolletta, S., \& Amicucci, L. (2015). The family experience of living with a person with amyotrophic lateral sclerosis: A qualitative study. International Journal of Psychology, 50(4), 288-294. https://doi.org/10.1002/ijop.12085

8. Cipolletta, S., Gammino, G. R., Francescon, P., \& Palmieri, A. (2018a). Mutual support groups for family caregivers of people with amyotrophic lateral sclerosis in Italy: A pilot study, (January), 556563. https://doi.org/10.1111/hsc. 12558

9. Cipolletta, S., Gammino, G. R., Francescon, P., \& Palmieri, A. (2018b). Mutual support groups for family caregivers of people with amyotrophic lateral sclerosis in Italy: A pilot study. Health and Social Care in the Community, 26(4), 556-563. https://doi.org/10.1111/hsc.12558

10. Corbin, J., \& Strauss, A. (2014). Basics of qualitative research: Techniques and procedures for developing grounded theory ( $4^{\text {th }}$ ed.). SAGE Publications, Thousand Oaks, CA

11. De Wit, J., Beelen, A., Drossaert, C. H. C., Kolijn, R., Van Den Berg, L. H., SchrÖder, C. D., \& Visser-Meily, J. M. A. (2020). Blended psychosocial support for partners of patients with ALS and PMA: results of 
a randomized controlled trial. Amyotrophic Lateral Sclerosis and Frontotemporal Degeneration, 21(5-6), 344-354. https://doi.org/10.1080/21678421.2020.1757114

12. Hogden, A., Foley, G., Henderson, R. D., \& James, N. (2017). Amyotrophic lateral sclerosis: improving care with a multidisciplinary approach. Journal of Multidisciplinary Healthcare, 205-215.

13. Jensen, M. P., Smith, A. E., Bombardier, C. H., Yorkston, K. M., Mir, J., \& Molton, I. R. (2013). Social support, depression , and physical disability: Age and diagnostic group effects. Disability and Health Journal, 7(2), 164-172. https://doi.org/10.1016/j.dhjo.2013.11.001

14. Kirk, S., \& Milnes, L. (2016). An exploration of how young people and parents use online support in the context of living with cystic fibrosis. Health Expectations, 19(2), 309-321.

https://doi.org/10.1111/hex.12352

15. Locock, L., \& Brown, J. B. (2010). Social Science \& Medicine 'All in the same boat '? Patient and carer attitudes to peer support and social comparison in Motor Neurone Disease ( MND ). Social Science \& Medicine, 71(8), 1498-1505. https://doi.org/10.1016/j.socscimed.2010.06.043

16. Macdonald, K., \& Greggans, A. (2010). ' Cool friends ': an evaluation of a community befriending programme for young people with cystic fibrosis. Journal of Clinical Nursing, 19(17-18), 24062414. https://doi.org/10.1111/j.1365-2702.2010.03294.x

17. Madsen, L. S., Jeppesen, J., \& Handberg, C. (2018). “ Understanding my ALS ”. Experiences and reflections of persons with amyotrophic lateral sclerosis and relatives on participation in peer group rehabilitation. Disability and Rehabilitation, O(0), 1-9.

https://doi.org/10.1080/09638288.2018.1429499

18. Marconi, A., Gragnano, G., Lunetta, C., Gatto, R., Fabiani, V., Tagliaferri, A., ... Pagnini, F. (2016). The experience of meditation for people with amyotrophic lateral sclerosis and their caregivers - a qualitative analysis. Psychology, Health and Medicine, 21(6), 762-768.

https://doi.org/10.1080/13548506.2015.1115110

19. Meade, O., Buchanan, H., \& Coulson, N. (2017). The use of an online support group for neuromuscular disorders: a thematic analysis of message postings analysis of message postings, 8288(June). https://doi.org/10.1080/09638288.2017.1334239

20. Mitchell, J. D., \& Borasio, G. D. (2007). Seminar Amyotrophic lateral sclerosis. Lancet, 369(9578), 2031-2041. https://doi.org/10.1016/S0140-6736(10)61156-7

21. Parkyn, H., \& Coveney, J. (2011). Child: An exploration of the value of social interaction in a boys ' group for adolescents with muscular dystrophy. Child: Care, Health and Development, 39(1), 1-9. https://doi.org/10.1111/j.1365-2214.2011.01353.x

22. Passoni, S., Moroni, L., Toraldo, A., Mazza, M. T., Bertolotti, G., Vanacore, N., \& Bottini, G. (2014). Cognitive Behavioral Group Intervention for Alzheimer Caregivers. Alzheimer Disease \& Associated Disorders, 28(3), 275-282. Retrieved from doi: 10.1097/WAD.0000000000000033

23. Pietkiewicz, I., Smith, J. A., Pietkiewicz, I., \& Smith, J. A. (2014). A practical guide to using Interpretative Phenomenological Analysis in qualitative research psychology, (2012), 7-14. https://doi.org/10.14691/CPPJ.20.1.7 
24. Siciliano, M., Trojano, L., Trojsi, F., Greco, R., \& Santangelo, G. (2017). Edinburgh Cognitive and Behavioural ALS Screen ( ECAS ) - Italian version: regression based norms and equivalent scores. Neurological Sciences, 38(6), 1059-1068. https://doi.org/10.1007/s10072-017-2919-4

25. Zarei, S., Carr, K., Reiley, L., Diaz, K., Guerra, O., Altamirano, P., ... Chinea, A. (2015). A comprehensive review of amyotrophic lateral sclerosis. Surgical Neurology International, 6(1), 171. https://doi.org/10.4103/2152-7806.169561

\section{Figures}

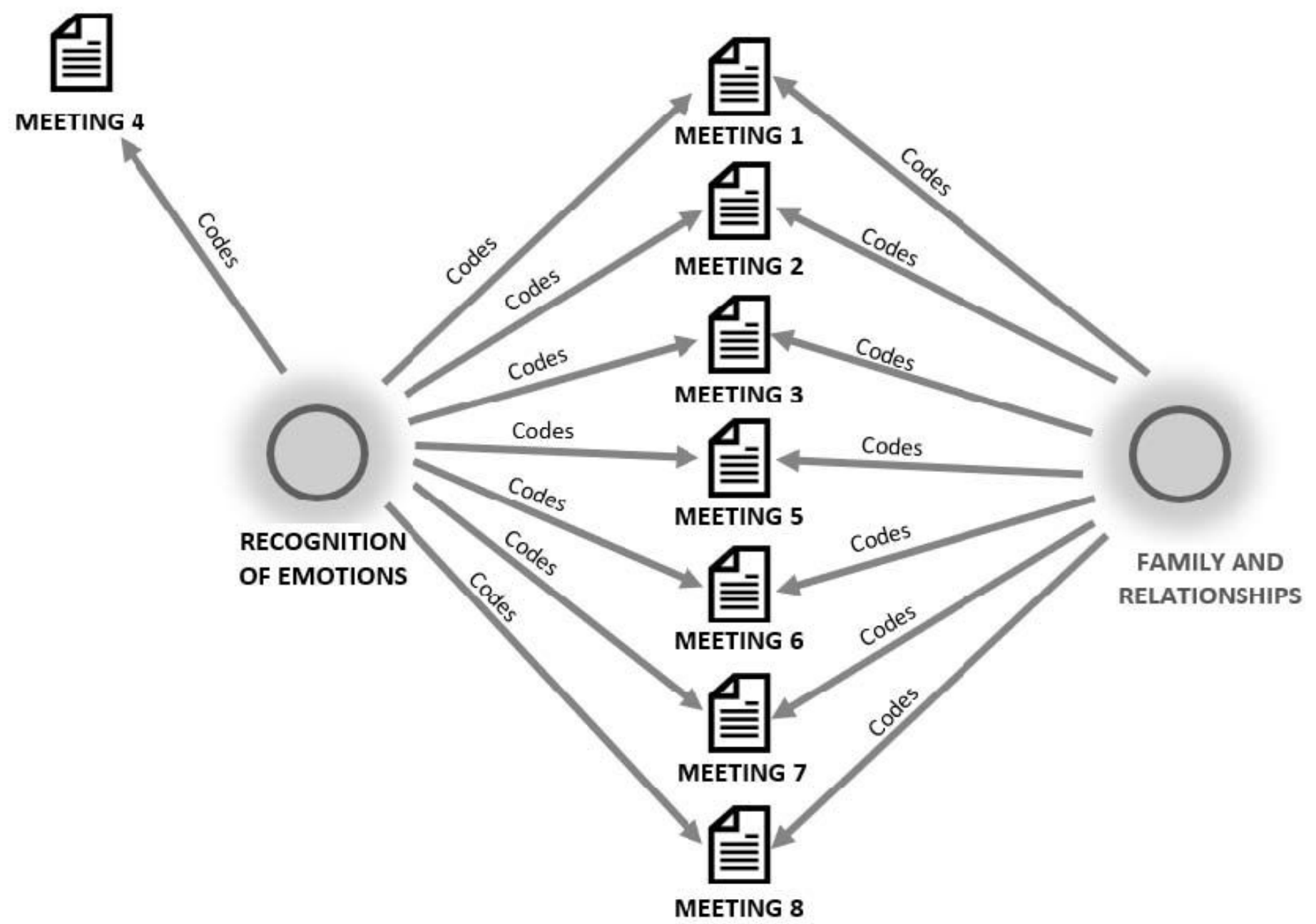

\section{Figure 1}

Comparison between Recognition of Emotions and Family and Relationships 


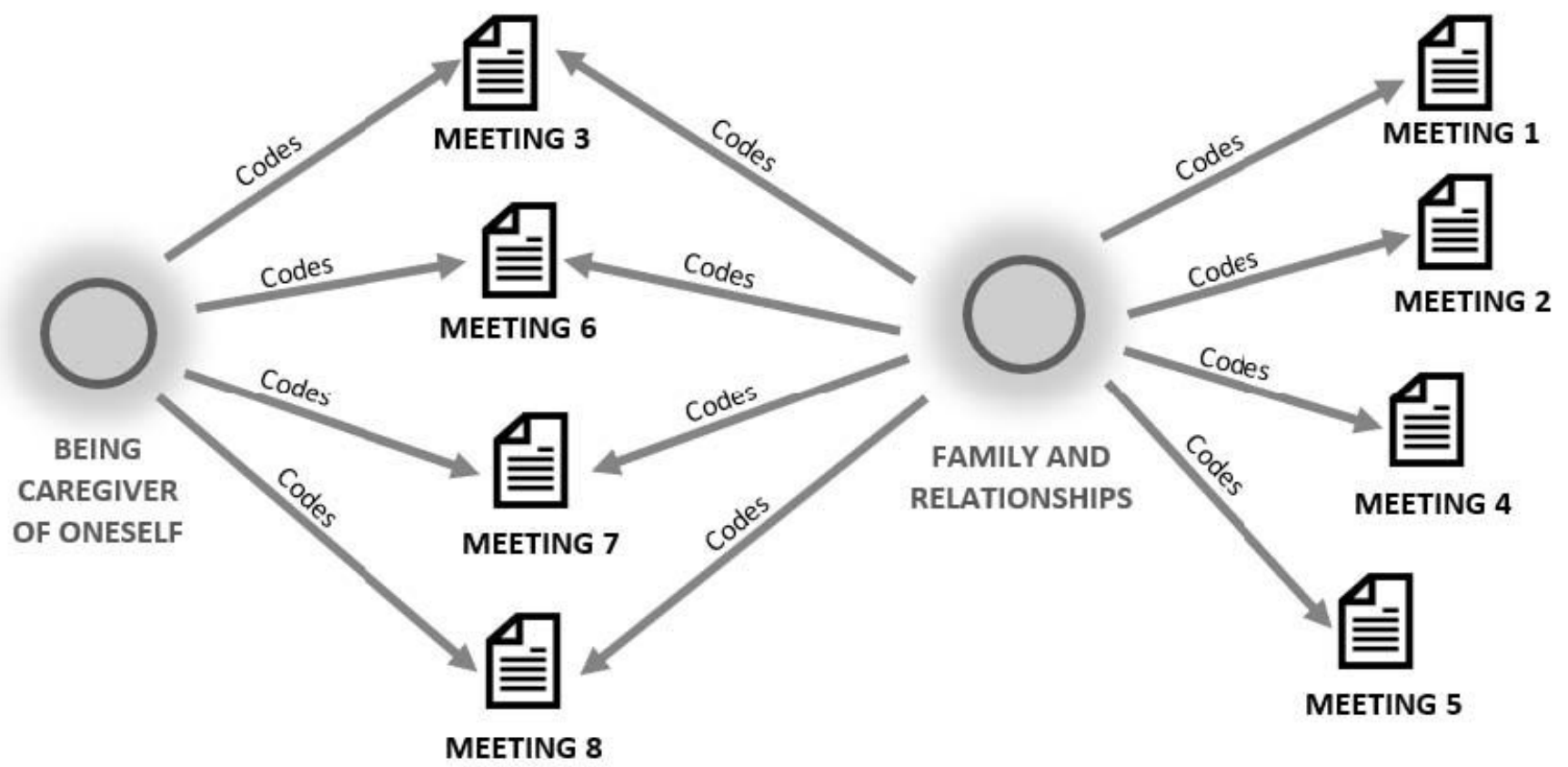

Figure 2

Comparison between Being Caregiver of Oneself and Family and Relationships 